\title{
Front Matter: Volume 8983
}

, "Front Matter: Volume 8983," Proc. SPIE 8983, Organic Photonic Materials and Devices XVI, 898301 (25 March 2014); doi: 10.1117/12.2063504

SPIE. Event: SPIE OPTO, 2014, San Francisco, California, United States 


\title{
PROCEEDINGS OF SPIE
}

\section{Organic Photonic Materials and Devices XVI}

\author{
Christopher E. Tabor \\ François Kajzar \\ Toshikuni Kaino \\ Yasuhiro Koike \\ Editors
}

3-5 February 2014

San Francisco, California, United States

Sponsored and Published by

SPIE 
The papers included in this volume were part of the technical conference cited on the cover and title page. Papers were selected and subject to review by the editors and conference program committee. Some conference presentations may not be available for publication. The papers published in these proceedings reflect the work and thoughts of the authors and are published herein as submitted. The publisher is not responsible for the validity of the information or for any outcomes resulting from reliance thereon.

Please use the following format to cite material from this book:

Author(s), "Title of Paper," in Organic Photonic Materials and Devices XVI, edited by Christopher E. Tabor, François Kajzar, Toshikuni Kaino, Yasuhiro Koike, Proceedings of SPIE Vol. 8983 (SPIE, Bellingham, WA, 2014) Article CID Number.

ISSN: 0277-786X

ISBN: 9780819498960

Published by

SPIE

P.O. Box 10, Bellingham, Washington 98227-0010 USA

Telephone +1 3606763290 (Pacific Time) · Fax +1 3606471445

SPIE.org

Copyright (C) 2014, Society of Photo-Optical Instrumentation Engineers.

Copying of material in this book for internal or personal use, or for the internal or personal use of specific clients, beyond the fair use provisions granted by the U.S. Copyright Law is authorized by SPIE subject to payment of copying fees. The Transactional Reporting Service base fee for this volume is $\$ 18.00$ per article (or portion thereof), which should be paid directly to the Copyright Clearance Center (CCC), 222 Rosewood Drive, Danvers, MA 01923. Payment may also be made electronically through CCC Online at copyright.com. Other copying for republication, resale, advertising or promotion, or any form of systematic or multiple reproduction of any material in this book is prohibited except with permission in writing from the publisher. The CCC fee code is 0277-786X/14/\$18.00.

Printed in the United States of America.

Publication of record for individual papers is online in the SPIE Digital Library.

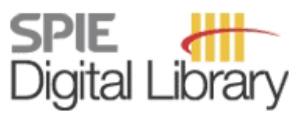

SPIEDigitalLibrary.org

Paper Numbering: Proceedings of SPIE follow an e-First publication model, with papers published first online and then in print and on CD-ROM. Papers are published as they are submitted and meet publication criteria. A unique, consistent, permanent citation identifier (CID) number is assigned to each article at the time of the first publication. Utilization of CIDs allows articles to be fully citable as soon as they are published online, and connects the same identifier to all online, print, and electronic versions of the publication. SPIE uses a six-digit CID article numbering system in which:

- The first four digits correspond to the SPIE volume number.

- The last two digits indicate publication order within the volume using a Base 36 numbering

system employing both numerals and letters. These two-number sets start with 00, 01, 02, 03, 04, $05,06,07,08,09,0 A, 0 B \ldots 0 Z$, followed by 10-1Z, 20-2Z, etc.

The CID Number appears on each page of the manuscript. The complete citation is used on the first page, and an abbreviated version on subsequent pages. Numbers in the index correspond to the last two digits of the six-digit CID Number. 


\section{Contents}

vii Conference Committee

NONLINEAR OPTICS I

898303 Optimization of the electronic third-order nonlinearity of cyanine-like molecules for all optical switching [8983-3]

H. Hu, T. R. Ensley, M. Reichert, CREOL, The College of Optics and Photonics, Univ. of Central Florida (United States); M. R. Ferdinandus, CREOL, The College of Optics and Photonics, Univ. of Central Florida (United States) and Air Force Institute of Technology (United States); D. Peceli, CREOL, The College of Optics and Photonics, Univ. of Central Florida (United States); O. V. Przhonska, CREOL, The College of Optics and Photonics, Univ. of Central Florida (United States) and National Academy of Sciences (Ukraine); S. R. Marder, Georgia Institute of Technology (United States); A. K.-Y. Jen, Univ. of Washington (United States); J. M. Hales, J. W. Perry, Georgia Institute of Technology (United States); D. J. Hagan, E. W. Van Stryland, CREOL, The College of Optics and Photonics, Univ. of Central Florida (United States) and Univ. of Central Florida (United States)

898304 Second-order nonlinear susceptibilities in nonelectrically poled DR1PMMA guest-host polymers [8983-4]

A. Sugita, Y. Sato, K. Ito, Y. Kawata, S. Tasaka, Shizuoka Univ. (Japan)

898305 Surface-plasmon-enhanced third-order harmonic generation of organic materials [8983-5] F. Ren, X. Wang, Oregon State Univ. (United States); Z. Li, J. Luo, S.-H. Jang, A. K.-Y. Jen, Univ. of Washington (United States); A. X. Wang, Oregon State Univ. (United States)

NONLINEAR OPTICS II

898307 Second harmonic generation at liquid interface: molecular organization, supramolecular assemblies, and chirality (Invited Paper) [8983-7]

E. Benichou, Institute Lumière Matière, CNRS, Univ. Claude Bernard Lyon 1, Univ. Lyon (France); P.-M. Gassin, Institute Lumière Matière, CNRS, Univ. Claude Bernard Lyon 1, Univ. Lyon (France) and Institut de Chimie Séparative de Marcoule, CEA-CNRS-UM2-ENSCM (France); G. Gassin-Martin, Institut Charles Gerhardt Montpellier, CNRS-UM2-ENSCM-UMI (France); A. Bruyère, I. Russier-Antoine, C. Jonin, Institute Lumière Matière, CNRS, Univ. Claude Bernard Lyon 1, Univ. Lyon (France); O. Diat, Institut de Chimie Séparative de Marcoule, CEA-CNRS-UM2-ENSCM (France); P.-F. Brevet, Institute Lumière Matière, CNRS, Univ. Claude Bernard Lyon 1, Univ. Lyon (France)

\section{OLED AND OLET}

8983 OC Progress of OLED devices with high efficiency at high luminance (Invited Paper) [8983-12] C. Nguyen, G. Ingram, Z.-H. Lu, Univ. of Toronto (Canada) 
8983 OD Optical properties of sulfur copolymers for infrared applications [8983-13]

S. Namnabat, College of Optical Sciences, The Univ. of Arizona (United States);

J. J. Gabriel, J. Pyun, The Univ. of Arizona (United States); R. A. Norwood, College of Optical

Sciences, The Univ. of Arizona (United States)

8983 OE Multidirectional waveguide arrays in a planar architecture [8983-14]

I. D. Hosein, H. Lin, M. R. Ponte, D. Baskar, K. Saravanamuttu, McMaster Univ. (Canada)

$89830 \mathrm{G}$ Longitudinal versus transversal excitation in doped graded-index polymer optical fibers [8983-16]

M. A. Illarramendi, J. Arrue, I. Ayesta, F. Jiménez, J. Zubia, I. Bikandi, Univ. del País Vasco

(Spain); A. Tagaya, Y. Koike, Keio Univ. (Japan)

8983 ol Proteins detection by polymer optical fibers sensitised with overlayers of block and random copolymers [8983-18]

A. El Sachat, A. Meristoudi, C. Markos, S. Pispas, C. Riziotis, National Hellenic Research

Foundation (Greece)

\section{NANO PHOTONIC}

$8983 \mathrm{OL}$ Laser inscription of surface structures and induction of optical anisotropy in azo-benzene substituted photochromic polymers and other systems (Invited Paper) [8983-21]

A. Miniewicz, L. Sznitko, E. N. Szlapa, P. Karpinski, A. C. Mitus, G. Pawlik, Wroclaw Univ. of Technology (Poland); E. Schab-Balcerzak, Polish Academy of Sciences (Poland) and Univ. of Silesia (Poland)

$89830 \mathrm{M}$ Epitaxial growth of a methoxy-functionalized organic semiconductor on dielectric surfaces [8983-22]

F. Balzer, R. Sun, H.-G. Rubahn, Univ. of Southern Denmark (Denmark); M. Schiek, Carl von Ossietzky Univ. Oldenburg (Denmark); A. Lützen, Rheinische Friedrich-Wilhelms-Univ. Bonn (Germany)

\section{PATTERN FORMATION}

898300 Fully updatable holographic stereogram display device based on organic monolithic compound [8983-24]

N. Tsutsumi, K. Kinashi, Kyoto Institute of Technology (Japan); K. Tada, K. Fukuzawa, Y. Kawabe, Chitose Institute of Science and Technology (Japan)

8983 OP Numerical studies on self-organized liquid crystal micro photonic systems [8983-25] T. Matsui, M. Kitaguchi, A. Okajima, Mie Univ. (Japan)

$89830 Q \quad$ Photorefractive device using self-assembled monolayer coated indium-tin-oxide electrodes [8983-26]

K. Kinashi, K. Masumura, W. Sakai, N. Tsutsumi, Kyoto Institute of Technology (Japan) 
8983 OR Two-photon solvatochromism of 4-dimethylamino-4'-nitrostilbene (DANS) [8983-27]

G. Wicks, A. Rebane, M. Drobizhev, Montana State Univ. (United States)

8983 OV Random lasing in liquid and solid solutions oversaturated with organic laser dye [8983-31] L. Sznitko, K. Cyprych, A. Szukalski, A. Miniewicz, J. Mysliwiec, Wroclaw Univ. of Technology (Poland)

8983 OW Polymeric waveguide Fabry Perot resonators [8983-32] M. A. Tadayon, Univ. of Minnesota (United States); M.-E. Baylor, Carleton College (United States); S. Ashkenazi, Univ. of Minnesota (United States)

OPV

898310 Efficient small-molecule photovoltaic cells using nanostructured template (Invited Paper) [8983-37]

T. Taima, Kanazawa Univ. (Japan) and Japan Science and Technology Agency (Japan); Y. Zhou, T. Kuwabara, K. Takahashi, Kanazawa Univ. (Japan)

\section{EO-POLYMER DEVICES}

898316 All-Polymer modulator for high frequency low drive voltage applications [8983-44] D. L. K. Eng, S. Kozacik, S. Shi, B. C. Olbricht, D. W. Prather, Univ. of Delaware (United States)

898317 Dual slot modulator for millimeter wave photonics [8983-45]

M. R. Konkol, S. T. Kozacik, D. L. K. Eng, B. Overmiller, M. J. Zablocki, B. C. Olbricht, J. Murakowski, S. Shi, Univ. of Delaware (United States); A. Sharkawy, EM Photonics (United States); D. W. Prather, Univ. of Delaware (United States)

\section{BIOPHOTONICS}

89831 A Latest advances in biomaterials: from deoxyribonucleic acid to nucleobases (Invited Paper) [8983-48]

F. Ouchen, Univ. of Dayton Research Institute (United States) and Air Force Research Lab. (United States); E. Gomez, Univ. of Cincinnati (United States); D. Joyce, A. Williams, Air Force Research Lab. (United States); S. Kim, Air Force Research Lab. (United States) and UES, Inc. (United States); E. Heckman, Air Force Research Lab. (United States); L. Johnson, Univ. of Washington (United States); P. Yaney, Air Force Research Lab. (United States) and Univ. of Dayton (United States); N. Venkat, Univ. of Dayton Research Institute (United States) and Air Force Research Lab. (United States); A. Steckl, Univ. of Cincinnati (United States); F. Kajzar, I. Rau, Univ. Politehnica of Bucharest (Romania); A. Pawlicka, Univ. de São Paulo (Brazil); P. Prasad, Univ. at Buffalo, SUNY (United States); J. Grote, Air Force Research Lab. (United States) 
8983 ID Bio-hybrid integrated system for wide-spectrum solar energy harvesting [8983-50] K. Martin, M. Erdman, The Univ. of New Mexico (United States); H. Quintana, New Mexico State Univ. (United States); J. Shelnutt, J. Nogan, B. Swartzentruber, Ctr. for Integrated Nano Technologies (United States); J. Martinez, New Mexico State Univ. (United States); O. Lavrova, T. Busani, The Univ. of New Mexico (United States)

POSTER SESSION

8983 IE Triphenylamine-based acrylate polymers for photorefractive composite [8983-51] H. N. Giang, K. Kinashi, W. Sakai, N. Tsutsumi, Kyoto Institute of Technology (Japan)

8983 IF FDTD analysis of photonic nanojet from self-organized liquid crystal microsystems [8983-52] A. Okajima, T. Matsui, Mie Univ. (Japan)

8983 1H Diffraction can mimic saturation in multiphoton absorbers [8983-54] M. Potasek, E. Parilov, Simphotek Inc. (United States); M. Walker, General Dynamics Information Technology (United States)

8983 iN Surface charge measurements and (dis)charging dynamics of organic semiconductors in various media using optical tweezers [8983-60]

R. R. Grollman, K. Peters, O. Ostroverkhova, Oregon State Univ. (United States)

898310 Sustainable UV-curable low refractive index resins with novel polymers for polymer cladding materials [8983-61]

H. Tokoro, T. Ishikawa, N. Koike, Y. Yamashina, DIC Corp. (Japan)

8983 IP Synthesis and electro-optic properties of the chromophore-containing NLO polyarylate polymers [8983-62]

H. Ren, Technical Institute of Physics and Chemistry (China); C. Peng, Technical Institute of Physics and Chemistry (China) and Graduate Univ. of Chinese Academy of Sciences (China); S. Bo, G. Fan, G. XU, H. Zhao, Z. Zhen, X. Liu, Technical Institute of Physics and Chemistry (China)

8983 1Q Design of Mach-Zehnder interference modulators composed of enhanced electro-optic active polymers [8983-63]

G. Xu, J. Liu, H. Ren, G. Fan, Z. Zhen, X. Liu, Technical Institute of Physics and Chemistry (China)

Author Index 


\section{Conference Committee}

Symposium Chairs

David L. Andrews, University of East Anglia Norwich (United Kingdom)

Alexei L. Glebov, OptiGrate Corporation (United States)

Symposium Cochairs

Jean Emmanuel Broquin, IMEP-LAHC (France)

Shibin Jiang, AdValue Photonics, Inc. (United States)

Program Track Chair

James G. Grote, Air Force Research Laboratory (United States)

Conference Chairs

Christopher E. Tabor, Air Force Research Laboratory (United States)

François Kajzar, Universitatea Politehnica of Bucharest (Romania)

Toshikuni Kaino, Tohoku University (Japan)

Yasuhiro Koike, Keio University (Japan)

Conference Program Committee

Chantal Andraud, Ecole Normale Supérieure de Lyon (France)

Werner J. Blau, Trinity College Dublin (Ireland)

Andreas Bräuer, Fraunhofer-Institut für Angewandte Optik und Feinmechanik (Germany)

Fabrice Charra, Commissariat à l'Énergie Atomique (France)

Raluca Dinu, GigOptix, Inc. (United States)

Manfred Eich, Technische Universität Hamburg-Harburg (Germany)

Alain F. Fort, Institut de Physique et Chimie des Matériaux de Strasbourg (France)

James G. Grote, Air Force Research Laboratory (United States)

F. Kenneth Hopkins, Air Force Research Laboratory (United States)

Alex K. Y. Jen, University of Washington (United States)

Michael H. C. Jin, Johns Hopkins University Applied Physics Laboratory (United States)

Eunkyoung Kim, Yonsei University (Korea, Republic of)

Jang-Joo Kim, Seoul National University (Korea, Republic of)

Nakjoong Kim, Hanyang University (Korea, Republic of)

Isabelle N. Ledoux-Rak, Ecole Normale Supérieure de Cachan

(France) 
Charles Y. C. Lee, Air Force Office of Scientific Research (United States)

Kwang-Sup Lee, Hannam University (Korea, Republic of)

Misoon Y. Mah, Asian Office of Aerospace Research and

Development (Japan)

Seth R. Marder, Georgia Institute of Technology (United States)

Antoni C. Mitus, Wroclaw University of Technology (Poland)

Jaroslaw Mysliwiec, Wroclaw University of Technology (Poland)

Robert L. Nelson, Air Force Research Laboratory (United States)

Robert A. Norwood, College of Optical Sciences, The University of Arizona (United States)

Jean-Michel Nunzi, Queen's University (Canada)

Shuji Okada, Yamagata University (Japan)

Akira Otomo, National Institute of Information and Communications Technology (Japan)

lleana Rau, Universitatea Politehnica of Bucharest (Romania)

Niyazi Serdar Sariciftci, Johannes Kepler Universität Linz (Austria)

Devanand K. Shenoy, Defense Advanced Research Projects Agency (United States)

Kenneth D. Singer, Case Western Reserve University (United States)

Attila A. Szep, Air Force Research Laboratory (United States)

Rebecca E. Taylor, Lockheed Martin Space Systems Company (United States)

Jeong-Weon Wu, Ewha Womans University (Korea, Republic of)

Shiyoshi Yokoyama, Kyushu University (Japan)

Roberto Zamboni, Istituto per la Sintesi Organica e la Fotoreattività (Italy)

\section{Session Chairs}

1 Nonlinear Optics I

Toshikuni Kaino, Tohoku University (Japan)

2 Nonlinear Optics II

Isabelle N. Ledoux-Rak, Ecole Normale Supérieure de Cachan (France)

3 OLED and OLET

Jean-Luc Bredas, Georgia Institute of Technology (United States)

4 Fiber and Waveguide

lleana Rau, Universitatea Politehnica of Bucharest (Romania)

5 Nano Photonic

François Kajzar, Universitatea Politehnica of Bucharest (Romania) 
6 Pattern Formation

Hiroshi Masuhara, National Chiao Tung University (Taiwan)

7 Absorption and Excitation

Andrzej Miniewicz, Wroclaw University of Technology (Poland)

8 Novel Polymers and Organics

Christopher E. Tabor, Air Force Research Laboratory (United States)

9 OPV

John R. Reynolds, Georgia Institute of Technology (United States)

10 EO-Polymer Devices

Toshikuni Kaino, Tohoku University (Japan)

11 Biophotonics

Eunkyoung Kim, Yonsei University (Korea, Republic of) 